\title{
JUURNAL.RU
}

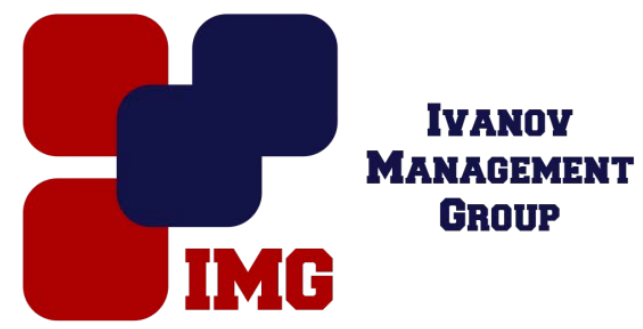

Старожилов В.Т. Тихоокеанский международньй ландшафтный центр ШЕН Дальневосточного федерального университета, д. геогр. н., профессор Владивосток, Россия

doi: 10.18411/lj-31-03-2017-2-16

idsp 000001:lj-31-03-2017-2-16

\section{Методика векторно-слоевого ландшафтного районирования горных территорий тихоокеанского ландшафтного пояса России}

Представляемая вниманию читателей работа является итогом многолетних научных исследований в сфере геолого-географического изучения и ландшафтного картографирования Тихоокеанского ландшафтного пояса крупного региона, расположенного в окраинно-континентальном секторе Азиатской части России [3]. Это горные территории, классические равнинные отсутствуют, выделяются предгорные и межгорные рифтогенные равнинные. Утверждая свое право на территориальный ландшафтный анализ и синтез, автор ранее рассматривал уже историю становления ландшафтной географии, место Приморья, о. Сахалин и др. [4] в системе ландшафтов России, используя ставшие классическими мелкомасштабные карты А.Г. Исаченко и И.С. Гудилина $[1,2]$. Также рассмотрены на основе применения картографирования и векторно-слоевых технологий вопросы классификации, дифференциации, высотности, внутреннего содержания ландшафтов на примере Приморского, Сахалинского и др. звеньев окраинно-континентального ландшафтного пояса Тихоокеанской России [4] .

На основе этих материалов и в результате применения методик синтеза, анализа и оценки внутреннего содержания ландшафтов региона, с учетом окраинно-континентальной дихотомии, на основе применения методологии учета межкомпонентных и межландшафтных связей на практике на примере Приморского, Сахалинского звеньев Тихоокеанского ландшафтного пояса проведено районирование. При картографировании региональных таксонов 
ландшафтов также применялись выделенные ранее ответственные за единые географические территории орографический, климатический и фиторастительный факторы. Важно отметить, что в целом в качестве основы для районирования прежде всего рассматривается весь пакет ландшафтных документов, полученных за последние десятилетия в результате применения современных компьютерных технологий и отображенных в векторно-слоевых картах ландшафтов масштабов 1: 500000 и 1 : 1000 000, (в частности в векторно-слоевой ландшафтной карте Приморского края $[5,6])$, в которых отображена информация по ландшафтам, их видам, родам, подклассам, классам (таблица 1).

\begin{tabular}{|c|c|c|}
\hline $\begin{array}{c}\text { Ландшафтная } \\
\text { единица }\end{array}$ & Критерий выделения & Примеры \\
\hline Класс & $\begin{array}{c}\text { Географическое единство, } \\
\text { сочетание зональных черт и } \\
\text { секторных различий, ярусность и } \\
\text { высотность } \\
\end{array}$ & дальневосточный горный \\
\hline Подкласс & $\begin{array}{c}\text { Высотность, типы } \\
\text { растительности }\end{array}$ & Смешанно-широколиственный \\
\hline Род & $\begin{array}{c}\text { Типы рельефа, субстрат, густота } \\
\text { горизонтального эрозионного } \\
\text { расчленения, глубина } \\
\text { эрозионного вреза }\end{array}$ & $\begin{array}{l}\text { Низкогорный терригенный, } \\
\text { низкогорный вулканогенно- } \\
\text { терригенный }\end{array}$ \\
\hline Вид & Растительность и почвы, рельеф & $\begin{array}{c}\text { Низкогорный терригенный дубовый } \\
\text { на горно-лесных бурых почвах }\end{array}$ \\
\hline Местность & $\begin{array}{c}\text { Сопряженные сочетания } \\
\text { однородного фундамента, } \\
\text { одинакового климата, форм } \\
\text { рельефа и группировок почв и } \\
\text { растительности }\end{array}$ & $\begin{array}{c}\text { Низкогорный широколиственный на } \\
\text { горно-лесных почвах с } \\
\text { алевролитовым вещественным } \\
\text { комплексом }\end{array}$ \\
\hline Урочище & $\begin{array}{c}\text { Сопряженные сочетания } \\
\text { однородных форм рельефа и } \\
\text { группировок почв и } \\
\text { растительности }\end{array}$ & $\begin{array}{c}\text { Низковершинные с ксерофитными } \\
\text { дубняками и их редколесьями на } \\
\text { бурых лесных маломощных } \\
\text { суглинистых сильно каменистых } \\
\text { эродированных почвах }\end{array}$ \\
\hline
\end{tabular}

Единицьы ландшафтов и критерии их выделения

Весь фактический материал на примере Приморского края оцифрован и в векторной системе был картографирован в масштабе 1: 500000 и 1: 1000 000, а для о. Русский - 1: 25000 . Затем весь материал в векторной системе с применением программ ГИС был разложен по «полочкам» (таксонам ландшафтов) с учетом критериев выделения соответствующего таксона. В результате на картах, согласно оцифрованного материала, были отражены слои соответствующих таксонов ландшафтов (таблица 1) и в конечном варианте мы получили слоевую ландшафтную карту соответствующей исследуемой территории. Важно отметить, что на окончательных векторно-слоевых ландшафтных картах в соответствующих границах отражены слои уже не 
отраслевых карт (геологические, геоморфологические, климатические, почвенные, геоботанические), а отражены в соответствующих выделах слои ландшафтных таксонов указанных в таблице 1, т.е. на картах отображены границы только слоев ландшафтов, а не границы отраслевых карт. Такие слоевые карты при условии применения компьютерных технологий позволяют оперативно работать на различных информационных уровнях с любым выделом и дают возможность оперативно получать карты по всем выделам отраженных на слоевых картах. В частности по Приморскому краю получено более 3156 ландшафтных карт по всем выделам (таблица 1).

Важно также отметить, что все выделенные на таких картах таксоны и их слои характеризуются внутренним качественным и количественным географическим содержанием, которое можно считывать или с карты или даже добавить данные в границах выделов дополнительно с других источников.

Отображенная на картах векторно-слоевая ландшафтная информация - это основа для векторно-слоевого картографирования других ландшафтных таксонов: округов, провинций, областей, районов, поясов, стран и других [7]. В целом, если говорить о методике районирования, то ландшафтное районирование может быть проведено только при наличии пакета ландшафтных материалов. В противном же случае, может быть выполнено только физикогеографическое районирование или зонирование.

В результате на среднемасштабном уровне, в частности в Приморье, выделены и картографированы ландшафтные округа, провинции, области. Особо отметим, что исследование по классификации единиц районирования на практике основывалось не на механическом картографирование ареалов, направленных на раскрытие механизма интеграции, а на фиксирование дифференциации и поиске эффектов сопряжения и внутреннего содержания таксонов на основе среднемасштабного ландшафтного картографирования. На учете важного в дифференциации территорий районирования ландшафтной сферы - фактора окраинно-континентальной дихотомии и в частности применительно к рассматриваемой для примера территории Приморья, где, как отмечалось выше, контрастно проявилось взаимодействие компонентов геосистемы океан - континент и играющий важную роль в обособлении по внутреннему содержанию географически единых территорий. Ниже приводится характеристика ландшафтных округов, провинций, областей.

В частности, округа обособляются внутри провинций, включают ландшафты отображенные векторно-слоевым методом (виды и местности), 
определяемые высотностью, типами растительности и группировками почв, рельефом и вещественными комплексами фундамента. Компьютерный поиск закономерностей в структуре и организации векторных ландшафтов, с учетом дифференциации векторных слоев местностей и видов и с учетом почвеннорастительного разнообразия, а также учетом глубинных корней окраинноконтинентальной дихотомии дал возможность выявить и векторно-слоевым методом отобразить на картах определенное количество округов ландшафтов.

Провинции обособляются внутри ландшафтных областей, включают ландшафты подклассов и родов, определяемые высотностью, типами растительности, рельефом и вещественными комплексами фундамента - тремя ведущими факторами: орографическому, климатическому и фиторастительному. Современное ландшафтное единство территории и в том числе провинций предопределено не только ходом геоморфологической, климатической эволюции, но и сложной историей геологического развития и формированием в различных структурно-тектонических зонах разнообразных осадочных, магматических, метаморфических пород, современных рыхлых отложений и образованием фундамента. Рассматривая целостность природы, вытекающую из взаимопроникновения друг в друга, взаимосвязанности и взаимообусловленности ее компонентов и факторов, в т. ч. фундамента как вещественного компонента и фактора ее эволюции, можно говорить о том, что и ответственные за формирование ландшафтов тектонические режимы (рубежные, флуктуационные и др.) и вещественные комплексы, консервативные компоненты, играют значимую роль в формировании структуры и пространственной организации и эволюции ландшафтов и ландшафтных единиц территорий. Поэтому, исходя из представления о равнозначности всех компонентов и факторов динамики ландшафтов и слабой, с позиций ландшафтной географии изученности его фундамента, были проведены дополнительные исследования.

По отмеченным выше ведущим сопряженным компонентным и ландшафтным особенностям и при учете установленных нами глубинных корней окраинно-континентальной дихотомии территорий ландшафтных областей выделяются геолого-геоморфологически целостные с единой для обособляемой территории растительной поясностью провинции. Например в Приморском крае выделено 12 провинций.

Области обособляются внутри ландшафтной страны, включают ландшафты одного класса, связанны с крупными тектоническими единицами и 
орографическими элементами (горными структурами, низменностями), одного зонального типа. Ранее отмечалось, что в условиях окраинно-континентальной дихотомии, весь ход геологического, геоморфологического и климатического развития территорий предопределил формирование и разделение территории на генетические географически целостные и внутренние единые территории. В частности в Приморском крае этому послужили общность исторического развития, географического положения горных складчатых Сихотэ-Алинской, Восточно-Маньчжурской, Южно-Приморской территорий и платформенной равнинной Уссури-Ханкайской. Такое структурное разделение территории Приморского края, в свою очередь, предопределило развитие горных и равнинных классов ландшафтов. Затем нами проведен сопряженный анализ и синтез связей компонентов внутреннего содержания классов ландшафтов, определены их границы и выделены ландшафтные области: Сихотэ-Алинская, Восточно-Маньчжурская, Южно-Приморская и Уссури-Ханкайская.

При этом, на основе синтеза и анализа отмеченных выше результатов, обособление областей, провинций и округов основывалось на установлении значимых генетически и географически взаимосвязанных, взаимообусловленных и взаимопрникающих друг в друга внутриобластных или внутрипровинциальных или внутриокружных факторов: орографического (рельеф, вещественные комплексы), климатического и фиторастительного (растительные комплексы) и обусловленных ими почвенных особенностей. При этом учитывалось, что фундамент это единая структурная и азональная вещественно-минеральная основа таксономических единиц районирования, на которой формируется соответствующие доминантные комплексы лесов и почв. Генетическое и географическое единство отмеченных орографического (рельеф, вешественные комплексы), климатического, фиторастительного (растительные комплексы) факторов обуславливают географическое обособление областей, провинций и округов.

Итак, в результате применения методологии сопряженного анализа межкомпонентных и межландшафтных связей на основе учета окраинноконтинентальной дихотомии, изучения орографического, климатического и фиторастительного факторов, обуславливающих генетическое и географическое единство ландшафтных территорий, а также применения векторных приемов ГИС и слоевого ландшафтного картографирования на примере Приморского края Тихоокеанского окраинно-континентального ландшафтного пояса разработана методика векторного слоевого ландшафтного районирования и 
изучения иерархической структуры и внутреннего географического содержания таксонов такого районирования в рамках горного ландшафтоведения. Разработанная методика применена на практике.

По отдельным регионам Тихоокеанского ландшафтного пояса, в частности по Приморскому краю, составлены векторные слоевые ландшафтные карты. Компьютерное использование таких векторных карт, как показала практика [8], значительно повышает оперативность их применения на всех информационных уровнях (планетарный, региональный, локальный) при решении вопросов оптимизации природопользовании и при освоении территорий Тихоокеанского ландшафтного пояса России. Разработанная методика векторного слоевого картографирования ландшафтов Приморского края применяется в настоящее время при составлении векторно-слоевой ландшафтной карты юга Тихоокеанской России и в частности Муравьев-Амурского округа и о. Русский. Мы полагаем, что практическая реализация разработанной компьютерной технологии векторно-слоевого ландшафтного картографирования должна быть первостепенной, базовой при планировании и осуществлении разномасштабных и разнопрофильных проектов деятельности организованного на базе ДВФУ Тихоокеанского международного ландшафтного центра, а также уже организованного при администрации Приморского края «центра развития территорий». Предложено центрам применять компьютерную технологию векторного слоевого картографирования и методику компьютерного пользования векторно-слоевыми ландшафтными картами и уже составленные векторно-слоевые ландшафтные карты в качестве «платформы» и основы для профессионального планирования и функционирования развития территорий. Использование уже разработанной ландшафтной платформы во многом скорректирует направления деятельности Тихоокеанского международного ландшафтного центра ДВФУ по оптимизации природопользования и в решении проблем охраны окружающей среды и экологии. В целом поможет в решении поставленных правительством практических задач по освоению территорий Тихоокеанской России и в развитии теоретической базы ландшафтной географии Ландшафтной сферы. Уже сегодня предлагается применять компьютерную технологию векторно-слоевого ландшафтного метода, особенно компьютерную технологию пользования ландшафтными материалами, как «платформу» в практическом осуществлении планов развития территорий приоритетных зон развития, таких как зона Надеждинского района и, в целом, зоны «Большой Владивосток». На уже составленных векторно-слоевых 
ландшафтных картах, кроме внутреннего природного содержания территорий, отражены природные границы отмеченных выше приоритетных зон развития. В частности границы зоны «Большого Владивостока» по природному содержанию, по нашему мнению, ограничиваются границей Муравьев-Амурского округа.

Кроме того, предлагается применять компьютерную технологию векторно-слоевого ландшафтного метода, особенно компьютерную технологию пользования ландшафтными материалами, как «платформу» в обучении студентов магистратуры по программе «Ландшафтное планирование».

\section{Литература}

1. Ландшафтная карта СССР масштаба 1: 2500 000. / Мин-во геологии СССР. / Отв. ред. И.С. Гудилин. - М.: Гидроспецгеология., 1980. 12 листов.

2. Ландшафтная карта СССР. Масштаб 1: 4000000 / науч. редактор Исаченко А.Г. М.: ГУГК, 1985. 2 листа.

3. Старожилов В.Т. Тихоокеанский окраинно-континентальный ландшафтный пояс как географическая единица Тихоокеанской России и вопросы практики // Проблемы региональной экологии. 2013а. №5. С. $1-7$.

4. Старожилов В.Т. Ландшафтная география Приморья (регионально-компонент-ная специфика и пространственный анализ геосистем). Владивосток: Изд-во Дальневост. федер. ун-та, 2013б. Часть 1. 276 с.

5. Старожилов В.Т. Карта ландшафтов Приморского края. Масштаб 1: 1000000. Владивосток: Изд-во Дальнев. ун-та. 2009а.1 лист.

6. Старожилов В.Т. Ландшафты Приморского края (Объяснительная записка к карте масштаба 1: 500 000). - Владивосток: Изд-во Дальнев. ун-та. 2009б. - 368 с.

7. Старожилов В.Т. Ландшафтная география Приморья. (районирование). - Владивосток: Изд-кий дом Дальнев. федер. ун-та, 2013в. Кн. 2. - 272 с.

8. Старожилов В.Т. Ландшафтная география Приморья (практика). Владивосток: Издский дом Дальнев. федер. ун-та, 2013г. Кн. 3. 276 с. 